\title{
Late-Onset Rasmussen's Syndrome with First Seizure during Pregnancy
}

\begin{tabular}{|l|l|l|}
\hline A.J. & Andrew J. & Larner \\
\hline S.J. & Shelagh J.M. & Smith \\
\hline J.S. & John S. & Duncan \\
\hline R.S. & Robin S. & Howard \\
\hline
\end{tabular}

National Hospital for Neurology and Neurosurgery, London, UK

\section{Dr. A.J. Larner, Department of Anatomy, Downing Street, Cambridge, CB2 3DY (UK)}

Rasmussen's syndrome of chronic encephalitis and epilepsy [1], characterized by intractable seizures, progressive sensorimotor deficit and cognitive decline, most frequently presents in children under 5 years of age [2]. Occasional reports of adult onset Rasmussen's syndrome have appeared [2-4]. We report a further adult case with seizure onset in the first trimester of pregnancy.

A right-handed Caucasian female suffered her first tonic-clonic seizure at age 22; it was subsequently discovered that she was 3 weeks pregnant at the time. Seizures recurred after delivery with increasing frequency (up to 20 times/day) and included focal motor, focal sensory, complex partial, adversive and secondarily generalized types, as well as repeated episodes of complex partial status. Seizures were uncontrolled by a variety of anti-epileptic drugs in various combinations, including phenytoin (maximum daily dose: $300 \mathrm{mg}$ ), carbama-zepine (1,200 mg), sodium valproate ( $2 \mathrm{~g}$ ), clonazepam ( $2 \mathrm{mg}$ ), phenobarbitone $(120 \mathrm{mg})$, acetazolamide $(500 \mathrm{mg})$, vigabatrin $(6 \mathrm{~g})$, clo-bazam $(30 \mathrm{mg})$ and lamotrigine $(200 \mathrm{mg})$. Over a period of 8 years the patient gradually developed an increasing fixed neurological deficit, including a macula splitting right homonymous hemianopia, expressive and receptive dysphasia, impaired dominant hemisphere skills (auditory verbal memory), IQ decline, right-sided sensory loss and right including a macula splitting right homonymous hemianopia, expressive and receptive dysphasia, impaired dominant hemisphere skills (auditory verbal memory), IQ decline, right-sided sensory loss and righ
upper motor neurone facial and limb weakness.

EEGs showed abnormal background activity and multifocal spike discharges in the left posterior quadrant. MRĪ showed increased signal on T2 weighted sequence superficially in the left temporo-occipi-tal cortex. Stereotactic biopsy of this area revealed a marked cortical astrocytic gliosis, scattered lymphocytes in the neuropil and perivascular lymphocyte cuffing in the white matter, but microglial nodules were not seen. In situ hybridisation for cytomegalovirus genome using a biotinylated DNA probe (Enzo Biochem, New York, USA) was negative. The biopsy appearances were felt to be in keeping with a chronic localized encephalitic pathology compatible with Rasmussen's syndrome, despite the absence of both microglial nodules [5] and CMV genome [6], neither of which rule out the diagnosis.

Concurrence of seizure onset with pregnancy may be the chance association of two unrelated phenomena, but it may reflect on the pathogenesis of Rasmussen's syndrome. Since oestrogens are known to be epileptogenic [7], pregnancy could reduce seizure threshold in a patient already harbouring a chronic, sub-clinical encephalitic process. However, in patients with established epilepsy pregnancy does not have a consistent effect on seizure control, but if worsening does occur, this is most likely in the first trimester [8]. Alternatively, the

depression of cell-mediated immunity in pregnancy could facilitate primary viral infection or reactivation of latent infection with cytomegalovirus [6] or Epstein-Barr virus [9], both of which have been implicated depression of cell-mediated immunity in pregnancy could facilitate primary viral infection or reactivation of latent infection with cytomegalovirus [6] or Epstein-Barr virus [9], both of which have been implicated
in the encephalitic process underlying Rasmussen’s syndrome. Moreover, it has been reported that alpha interferon, an agent with both immunomodulatory and antiviral activities, may improve both the seizure frequency and neurological deficit in Rasmussen's syndrome [10].

Acknowledgements

We thank Dr. R.W. Ross Russell for permission to report his patient; Professor D.G.T. Thomas for performing the stereotactic brain biopsy; and Professors L.W. Duchen and F. Scaravilli for histological studies. References

Rasmussen T, Olszewski J, Lloyd-Smith D: Focal seizures due to chronic localized encephalitis. Neurology 1958;8:435-445.

Oguni H, Andermann F, Rasmussen T: The natural history of the syndrome of chronic encephalitis and epilepsy: a study of the MNI series of forty-eight cases; in Andermann F (ed): Chronic Encephalitis and Epilepsy: Rasmussen’s Syndrome. Boston, Butterworth-Heinemann, 1991, pp 7-35.

Gray F, Serdaru M, Baron H, et al: Chronic localized encephalitis (Rasmussen’s) in an adult with epilepsia partialis continua. J Neurol Neurosurg Psychiatry 1987;50:747-751.

McLachlan RS, Girvin JP, Blume WT, Reichman H: Rasmussen’s chronic encephalitis in adults. Arch Neurol 1993;50:269-274.

Robitaille Y: Neuropathologic aspects of chronic encephalitis; in Andermann F (ed): Chronic Encephalitis and Epilepsy: Rasmussen's Syndrome. Boston, Butterworth-Heinemann, 1991, pp 79-110.

Power C, Poland SD, Blume WT, Girvin JP, Rice GPA: Cytomegalovirus and Rasmussen’s encephalitis. Lancet 1990;336:1282-1284.

Woolley DE, Timiras PS: The gonad-brain relationship: Effects of female sex hormones on electroshock convulsions in the rat. Endocrinology 1962; 70:196209.

Schmidt D, Canger R, Avanzini G, et al: Change of seizure frequency in pregnant epileptic women. J Neurol Neurosurg Psychiatry 1983;46:751-755.

Walter GF, Renella RR: Epstein-Barr virus in brain and Rasmussen’s encephalitis. Lancet 1989;i:279-280.

10 Maria BL, Ringdahl DM, Mickle JP, et al: Intraventricular alpha interferon therapy for Rasmussen’s syndrome. Can J Neurol Sci 1993;20:333-336. 